\title{
Effect of Different Levels of Seed Rate, Nitrogen and Zinc on Growth and Yield of Fodder Maize (Zea mays L.)
}

\author{
Tahira Begum ${ }^{1}$, B.S. Lalitha ${ }^{1 *}$ and C.T. Subbarayappa ${ }^{2}$ \\ ${ }^{1}$ Department of Agronomy, ${ }^{2}$ Department of Soil Science \& Agricultural Chemistry, University \\ of Agricultural Sciences, Bengaluru - 560 065, Karnataka, India \\ *Corresponding author
}

\section{Keywords}

Nitrogen, Zinc, Fodder maize, Growth, Dry matter accumulation and green fodder yield

Article Info

Accepted:

08 August 2018

Available Online:

10 September 2018

\section{A B S T R A C T}

Field experiment on Effect of different levels of seed rate, nitrogen and zinc on yield and quality of fodder maize (Zea mays L.) was conducted at Zonal Agricultural Research Station, UAS, GKVK, Bengaluru during kharif 2017. There were 18 treatment combinations involving 3 levels of seed rate $\left(50,75\right.$ and $\left.100 \mathrm{~kg} \mathrm{ha}^{-1}\right), 3$ nitrogen levels $\left(100,125\right.$ and $\left.150 \mathrm{~kg} \mathrm{ha}^{-1}\right)$ and 2 zinc levels $\left(0\right.$ and $\left.10 \mathrm{~kg} \mathrm{ha}^{-1}\right)$. The experiment was laid out in a FRCBD, replicated thrice. The results revealed that, seed rate of $75 \mathrm{~kg} \mathrm{ha}^{-1}$ recorded significantly higher dry matter accumulation (104.32 $\mathrm{g} \mathrm{plant}^{-1}$ ) and green fodder yield of $34.29 \mathrm{t} \mathrm{ha}^{-1}$ when compared to seed rate of $50 \mathrm{~kg} \mathrm{ha}^{-1}\left(98.60 \mathrm{~g} \mathrm{plant}^{-1}\right.$ and $29.58 \mathrm{t}$ $\mathrm{ha}^{-1}$ of dry matter accumulation and green fodder yield respectively), and was on par with seed rate $100 \mathrm{~kg} \mathrm{ha}^{-1}$ (102.75 $\mathrm{g} \mathrm{plant}^{-1}$ and $32.50 \mathrm{t} \mathrm{ha}^{-1}$ of dry matter accumulation and green fodder yield respectively). Application of $150 \mathrm{~kg}$ nitrogen ha ${ }^{-1}$ resulted significantly higher dry matter accumulation of $107.87 \mathrm{~g} \mathrm{plant}^{-1}$ and green fodder yield $\left(34.56 \mathrm{t} \mathrm{ha}^{-1}\right)$ over nitrogen at $100 \mathrm{~kg} \mathrm{ha}^{-1}$ and 125 nitrogen per ha. Application of $10 \mathrm{~kg} \mathrm{zinc} \mathrm{ha}^{-1}$ recorded significantly higher dry matter accumulation of $103.69 \mathrm{~g} \mathrm{plant}^{-1}$ and green fodder yield $\left(33.07 \mathrm{tha}^{-1}\right)$ over no zinc application $\left(30.78 \mathrm{t} \mathrm{ha}^{-1}\right)$.

\section{Introduction}

Fodder maize being highly nutritious and more palatability fodder among the different fodder and forage crops. There are many constraints for low productivity of fodder maize and among then maintaining optimum plant population is the major problem being a non tillering requires optimum seed rate to get higher population and in turn for more productivity per unit area. After seed rate important management factor for higher yield is nutrient management and among the essential nutrients, nitrogen is the most important limiting factor for plant growth. Nitrogen $(\mathrm{N})$ plays a very important role in crop productivity (Ahmad, 2000) and its deficiency is one of the major yields limiting factor for cereal production (Shah et al., 2003). Nitrogen plays the important role in vegetative growth and development of any crop and fodder and forages are harvested for 
vegetative biomass and to put forth more vegetative growth nitrogen require in abundance. Zinc micro nutrient deficiency appears to be the most widespread in most Indian soils and zinc play an important role in physiological functions in all living systems, for maintenance of structural and functional integrity of biological membranes and facilitation of protein synthesis and gene expression. In plants, zinc plays a key role as a structural constituent or regulatory co-factor of a wide range of different enzymes and proteins in many important biochemical pathways which are mainly concerned with carbohydrate metabolism, both in photosynthesis and in the conversion of sugars to starch, protein and auxin metabolism. The information available on seed rate, nitrogen and zinc levels was very meagre and therefore field experiment on effect of different seed rate, nitrogen and zinc on growth and yield was undertaken.

\section{Materials and Methods}

Field experiment on Effect of different levels of seed rate, nitrogen and zinc on yield and quality of fodder maize (Zea mays L.) was taken during the kharif 2017. The material used and methods used during the course investigation are described in this chapter. The experiment was conducted at Zonal Agricultural Research Station (ZARS), Gandhi Krishi Vignana Kendra, University of Agricultural Sciences, Bengaluru which is situated at $13^{\circ} 05^{\prime}$ North latitude and $77^{\circ} 34^{\prime}$ East longitude and at an altitude of $924 \mathrm{~m}$ above mean sea level which comes under eastern dry zone (ACZ-V) of Karnataka.

The experiment was laid out in RCBD with Factorial concept replicated thrice. The experiment consists of 18 treatments combination viz., 3 levels of seed rate $(50,75$ and $\left.100 \mathrm{~kg} \mathrm{ha}^{-1}\right), 3$ nitrogen levels $(100,125$ and $150 \mathrm{~kg} \mathrm{ha}^{-1}$ ) and 2 zinc levels ( 0 and $10 \mathrm{~kg}$ $\mathrm{ha}^{-1}$ ). Furrows were opened at $30 \mathrm{~cm}$ apart and $75 \mathrm{P}_{2} \mathrm{O}_{5}$ and $40 \mathrm{~kg} \mathrm{~K}_{2} \mathrm{O} \mathrm{kg} \mathrm{ha}{ }^{-1}$ applied through single super phosphate and muriate of potash respectively. Nitrogen 50 per cent basal and 50\% as top dressing 30 DAS was applied as per the treatments. Crop was sown on $2^{\text {nd }}$ August, 2017 and harvested at 50 per cent flowering to milking stage.

Five plant randomly selected in net plot area to take growth observation at different stage of crop growth. While harvesting crop from net plot area harvested separately as per treatments and values were converted into hectare basis and expressed in tones. The samples were first dried under shade and then in over at $65^{\circ} \mathrm{C}$ till attaining constant weight, the green fodder yield was converted into dry matter yield (t/ha). Later data was Panse and Sukhatme (1967)

\section{Treatment details}

$\mathrm{T}_{1}: 50 \mathrm{~kg}$ seed rate $+100 \mathrm{~kg}$ nitrogen $+0 \mathrm{~kg}$ zinc

$\mathrm{T}_{2}: 50 \mathrm{~kg}$ seed rate $+100 \mathrm{~kg}$ nitrogen $+10 \mathrm{~kg}$ zinc

$\mathrm{T}_{3}: 50 \mathrm{~kg}$ seed rate $+125 \mathrm{~kg}$ nitrogen $+0 \mathrm{~kg}$ zinc

$\mathrm{T}_{4}: 50 \mathrm{~kg}$ seed rate $+125 \mathrm{~kg}$ nitrogen $+10 \mathrm{~kg}$ zinc

$\mathrm{T}_{5}: 50 \mathrm{~kg}$ seed rate $+150 \mathrm{~kg}$ nitrogen $+0 \mathrm{~kg}$ zinc

$\mathrm{T}_{6}: 50 \mathrm{~kg}$ seed rate $+150 \mathrm{~kg}$ nitrogen $+10 \mathrm{~kg}$ zinc

$\mathrm{T}_{7}: 75 \mathrm{~kg}$ seed rate $+100 \mathrm{~kg}$ nitrogen $+0 \mathrm{~kg}$ zinc

$\mathrm{T}_{8}: 75 \mathrm{~kg}$ seed rate $+100 \mathrm{~kg}$ nitrogen $+10 \mathrm{~kg}$ zinc 
$\mathrm{T}_{9}: 75 \mathrm{~kg}$ seed rate $+125 \mathrm{~kg}$ nitrogen $+0 \mathrm{~kg}$
zinc
$\mathrm{T}_{10}: 75 \mathrm{~kg}$ seed rate $+125 \mathrm{~kg}$ nitrogen $+10 \mathrm{~kg}$
zinc

$\mathrm{T}_{11}: 75 \mathrm{~kg}$ seed rate $+150 \mathrm{~kg}$ nitrogen $+0 \mathrm{~kg}$ zinc

$\mathrm{T}_{12}: 75 \mathrm{~kg}$ seed rate $+150 \mathrm{~kg}$ nitrogen $+10 \mathrm{~kg}$ zinc

$\mathrm{T}_{13}: 100 \mathrm{~kg}$ seed rate $+100 \mathrm{~kg}$ nitrogen $+0 \mathrm{~kg}$ zinc

$\mathrm{T}_{14}: 100 \mathrm{~kg}$ seed rate $+100 \mathrm{~kg}$ nitrogen +10 $\mathrm{kg}$ zinc

$\mathrm{T}_{15}: 100 \mathrm{~kg}$ seed rate $+125 \mathrm{~kg}$ nitrogen $+0 \mathrm{~kg}$ zinc

$\mathrm{T}_{16}: 100 \mathrm{~kg}$ seed rate $+125 \mathrm{~kg}$ nitrogen +10 $\mathrm{kg}$ zinc

$\mathrm{T}_{17}: 100 \mathrm{~kg}$ seed rate $+150 \mathrm{~kg}$ nitrogen $+0 \mathrm{~kg}$ zinc

$\mathrm{T}_{18}: 100 \mathrm{~kg}$ seed rate $+150 \mathrm{~kg}$ nitrogen +10 $\mathrm{kg}$ zinc

\section{Observations on growth parameters}

The various growth parameters such as plant height, number of leaves plant ${ }^{-1}$, leaf: stem ratio and dry matter accumulation

\section{Plant height}

The plant height $(\mathrm{cm})$ was recorded from five randomly selected and labelled plants.

Plant height was taken from the base of the plant to tip of the newly opened leaf.

The mean plant height was worked out and expressed in centimeter.

\section{Number of leaves}

Total number of fully opened green leaves of five plants was counted and their average was taken as the number of leaves plant ${ }^{-1}$.

\section{Leaf: stem ratio}

Leaf: stem ratio was calculated from five randomly selected plants from each plot. The leaves were separated from the stem and fresh weight of both leaves and stem were noted separately and leaf: stem ratio is calculated by dividing the leaves weight by stem weight and expressed in ratio.

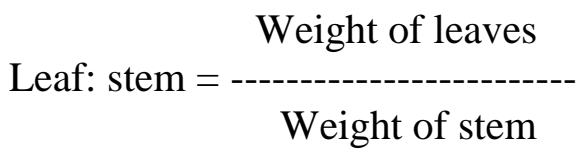

\section{Dry matter accumulation}

At each sampling after recording the observations, the plants were uprooted and oven dried at $65^{\circ} \mathrm{C}$ to a constant weight. The mean of five plants in each treatment was calculated and expressed in $g$ per plant.

\section{Observation on yield parameter}

\section{Green fodder yield}

Green fodder yield from each net plot ( $\mathrm{kg} \mathrm{plot}^{-}$ ${ }^{1}$ ) was recorded after harvest of the crop and converted into tonnes per hectare.

\section{Statistical analysis and interpretation of data}

The experimental data collected on growth, yield and quality components of plant were subjected to Fisher's method of "Analysis of Variance" (ANOVA) as outlined by Panse and Sukhatme (1967). Wherever, F- test was significant, for comparison among the treatment means, an appropriate value of 
critical difference (C.D.) was worked out. If Ftest found non-significant, against C.D. values NS (Non-Significant) was indicated. All the data were analyzed and the results were presented and discussed at a probability level of five per cent.

\section{Results and Discussion}

\section{Plant height}

Significantly higher plant height was recorded with seed rate of $75 \mathrm{~kg}$ per ha $(179.49 \mathrm{~cm})$ as compared to seed rate of $50 \mathrm{~kg}$ per ha $(160.16$ $\mathrm{cm})$ and it was on par with seed rate of $100 \mathrm{~kg}$ per ha $(170.48 \mathrm{~cm})$. Significantly higher plant height at seed rate of $75 \mathrm{~kg}$ per ha was mainly due to reduced competition within the intra row spacing as compared to higher seed rate of $100 \mathrm{~kg}$ per ha. The findings are in conformation of the results of Abdulgani et al., (2018).

Plant height differed significantly due to the nitrogen levels and higher plant height of $181.89 \mathrm{~cm}$ was obtained with the application of $150 \mathrm{~kg}$ nitrogen per ha compared to $100 \mathrm{~kg}$ nitrogen per ha. The positive effect of nitrogen on the plant vegetative that led to progressive increase in the internode length.

These results collaborate with the finding of Eltelib et al., (2006), Mehdi et al., (2012). Zinc at $10 \mathrm{~kg}$ per ha has significantly increased the plant height of fodder maize $(175.69 \mathrm{~cm})$ as compared to no zinc application. Since zinc helps in the biosynthesis of Indole 3 -acetic acid, a growth hormone, enhances stem elongation, hence the increase in the plant height. Earlier Patel et al., (2007) and also described a significantly increase in the plant height of fodder maize with soil application of zinc over its foliar application and control. The interactions between seed rate, nitrogen and zinc levels found not significant (Table 1).

\section{Number of leaves}

Different levels of seed rate did not cause any significant influence on the number of leaves plant $^{-1}$. Significant increase was observed in number of leaves per plant with increase in the nitrogen at $150 \mathrm{~kg}$ per ha (13.19) as compared to application of $100 \mathrm{~kg}$ nitrogen per ha (11.00). An increase in number of green leaves might be due to the availability of sufficient amount of nitrogen in all the growth stages. Increased plant height resulted in more number of nodes per plant which accommodated more number of leaves per plant. Again nitrogen helped in rapid growth and development of plants as they help in photosynthesis and various plant biochemical processes which responds towards growt. Zinc application at $10 \mathrm{~kg}$ per ha significantly increased the number of leaves plant ${ }^{-1}$ of the fodder maize (12.55) over no zinc application (11.80). It was due to synergistic effect of both nitrogen and zinc on growth and development of plants. The results are in confirmation with the findings of Surendra Mohan (2015). All the interactions were found non-significant.

\section{Leaf: stem ratio}

Significantly higher leaf: stem ratio was recorded with seed rate of $75 \mathrm{~kg}$ per ha (0.56) as compared to seed rate of $50 \mathrm{~kg}$ per ha (0.50) and it was on par with seed rate of 100 $\mathrm{kg}$ per ha $(0.55)$. The higher leaf: stem ratio with the seed rate of $75 \mathrm{~kg}$ per ha was due to increased leaf size and decreased stem girth. In higher seed rate because of more population per unit area led to grassy shoot appearance. At lower seed rate, more space is available for crop growth and development resulted in more stem girth which led to lower leaf: stem ratio similar results were reported by Verma (2005) and Bishnol et al., (2005). Fodder maize at $150 \mathrm{~kg}$ nitrogen per ha recorded significantly higher leaf: stem ratio (0.60) as compared to $100 \mathrm{~kg}$ nitrogen per ha (0.48). 
Table.1 Plant height, number of leaves and leaf: stem ratio of fodder maize at harvest as influenced by different levels of seed rate nitrogen and zinc

\begin{tabular}{|c|c|c|c|c|c|c|c|}
\hline Treatments & $\begin{array}{l}\text { Plant } \\
\text { height } \\
\text { (cm) }\end{array}$ & $\begin{array}{l}\text { Number } \\
\text { of leaves } \\
\text { plant }^{-1}\end{array}$ & $\begin{array}{l}\text { Leaf: stem } \\
\text { ratio }\end{array}$ & Treatments & $\begin{array}{l}\text { Plant } \\
\text { height } \\
(\mathrm{cm})\end{array}$ & $\begin{array}{l}\text { Number } \\
\text { of leaves } \\
\text { plant }^{-1}\end{array}$ & $\begin{array}{l}\text { Leaf: stem } \\
\text { ratio }\end{array}$ \\
\hline \multicolumn{4}{|c|}{ Seed rates $(\mathbf{S})$} & \multicolumn{4}{|c|}{ Interaction ( $\mathrm{N} \times \mathrm{Zn})$} \\
\hline $\mathbf{S}_{1}$ & 160.16 & 12.15 & 0.49 & $\mathrm{~N}_{1} \mathrm{Zn}_{0}$ & 158.33 & 11.15 & 0.46 \\
\hline $\mathbf{S}_{2}$ & 179.49 & 12.28 & 0.56 & $\mathrm{~N}_{1} \mathrm{Zn}_{1}$ & 163.31 & 12.09 & 0.48 \\
\hline $\mathbf{S}_{3}$ & 170.48 & 12.20 & 0.55 & $\mathrm{~N}_{2} \mathrm{Zn}_{0}$ & 167.00 & 11.53 & 0.52 \\
\hline S.Em \pm & 3.49 & 0.27 & 0.01 & $\mathrm{~N}_{2} \mathrm{Zn}_{1}$ & 176.55 & 12.17 & 0.54 \\
\hline CD 5\% & 10.04 & NS & 0.03 & $\mathrm{~N}_{3} \mathrm{Zn}_{0}$ & 176.55 & 13.00 & 0.57 \\
\hline \multicolumn{4}{|c|}{ Nitrogen level (N) } & $\mathrm{N}_{3} \mathrm{Zn}_{0}$ & 187.22 & 13.39 & 0.62 \\
\hline $\mathbf{N}_{1}$ & 160.82 & 11.00 & 0.47 & S. Em \pm & 4.94 & 0.38 & 0.02 \\
\hline $\mathbf{N}_{2}$ & 171.77 & 11.85 & 0.53 & $\mathrm{CD}$ at $5 \%$ & NS & NS & NS \\
\hline $\mathbf{N}_{3}$ & 181.89 & 13.19 & 0.60 & \multicolumn{4}{|c|}{ Interaction (S x N x Zn) } \\
\hline S.Em \pm & 3.49 & 0.27 & 0.01 & $\mathrm{~S}_{1} \mathrm{~N}_{1} \mathrm{Zn}_{0}$ & 153.33 & 11.00 & 0.46 \\
\hline CD at $5 \%$ & 10.04 & 0.78 & 0.03 & $\mathrm{~S}_{1} \mathrm{~N}_{1} \mathrm{Zn}_{1}$ & 157.00 & 11.33 & 0.47 \\
\hline \multicolumn{4}{|c|}{ Zinc level (Zn) } & $\mathrm{S}_{1} \mathrm{~N}_{2} \mathrm{Zn}_{0}$ & 158.67 & 12.00 & 0.49 \\
\hline $\mathbf{Z n}_{0}$ & 167.29 & 11.80 & 0.50 & $\mathrm{~S}_{1} \mathrm{~N}_{2} \mathrm{Zn}_{1}$ & 166.00 & 12.33 & 0.50 \\
\hline $\mathbf{Z n}_{1}$ & 175.69 & 12.55 & 0.55 & $\mathrm{~S}_{1} \mathrm{~N}_{3} \mathrm{Zn}_{0}$ & 169.33 & 13.00 & 0.52 \\
\hline S.Em \pm & 2.85 & 0.22 & 0.01 & $\mathrm{~S}_{1} \mathrm{~N}_{3} \mathrm{Zn}_{1}$ & 180.67 & 13.33 & 0.55 \\
\hline CD at $5 \%$ & 8.19 & 0.63 & 0.02 & $\mathrm{~S}_{2} \mathrm{~N}_{1} \mathrm{Zn}_{0}$ & 166.33 & 11.27 & 0.47 \\
\hline \multicolumn{4}{|c|}{ Interaction (S x N) } & $\mathrm{S}_{2} \mathrm{~N}_{1} \mathrm{Zn}_{1}$ & 171.27 & 11.60 & 0.49 \\
\hline $\mathbf{S}_{1} \mathbf{N}_{1}$ & 150.16 & 11.17 & 0.46 & $\mathrm{~S}_{2} \mathrm{~N}_{2} \mathrm{Zn}_{0}$ & 177.33 & 12.00 & 0.56 \\
\hline $\mathbf{S}_{1} \mathbf{N}_{2}$ & 160.33 & 12.17 & 0.49 & $\mathrm{~S}_{2} \mathrm{~N}_{2} \mathrm{Zn}_{1}$ & 182.67 & 12.33 & 0.58 \\
\hline $\mathbf{S}_{1} \mathbf{N}_{3}$ & 170.00 & 13.17 & 0.53 & $\mathrm{~S}_{2} \mathrm{~N}_{3} \mathrm{Zn}_{0}$ & 187.00 & 13.00 & 0.61 \\
\hline $\mathbf{S}_{2} \mathbf{N}_{1}$ & 168.80 & 11.43 & 0.47 & $\mathrm{~S}_{2} \mathrm{~N}_{3} \mathrm{Zn}_{1}$ & 192.33 & 13.50 & 0.68 \\
\hline $\mathbf{S}_{2} \mathbf{N}_{2}$ & 180.00 & 12.17 & 0.56 & $\mathrm{~S}_{3} \mathrm{~N}_{1} \mathrm{Zn}_{0}$ & 155.33 & 11.19 & 0.48 \\
\hline $\mathbf{S}_{2} \mathbf{N}_{3}$ & 189.66 & 13.25 & 0.64 & $\mathrm{~S}_{3} \mathrm{~N}_{1} \mathrm{Zn}_{1}$ & 161.67 & 13.33 & 0.50 \\
\hline $\mathbf{S}_{3} \mathbf{N}_{1}$ & 158.50 & 12.26 & 0.48 & $\mathrm{~S}_{3} \mathrm{~N}_{2} \mathrm{Zn}_{0}$ & 165.00 & 10.60 & 0.53 \\
\hline $\mathbf{S}_{3} \mathbf{N}_{2}$ & 173.00 & 11.22 & 0.54 & $\mathrm{~S}_{3} \mathrm{~N}_{2} \mathrm{Zn}_{1}$ & 181.00 & 11.83 & 0.56 \\
\hline $\mathbf{S}_{3} \mathbf{N}_{3}$ & 181.00 & 13.17 & 0.62 & $\mathrm{~S}_{3} \mathrm{~N}_{3} \mathrm{Zn}_{0}$ & 182.50 & 13.00 & 0.59 \\
\hline S.Em \pm & 6.05 & 0.47 & 0.02 & $\mathrm{~S}_{3} \mathrm{~N}_{3} \mathrm{Zn}_{1}$ & 188.67 & 13.33 & 0.65 \\
\hline CD 5\% & NS & NS & NS & S. Em \pm & 8.55 & 0.66 & 0.03 \\
\hline \multicolumn{4}{|c|}{ Interaction (S x Zn) } & $\mathrm{CD}$ at $5 \%$ & NS & NS & NS \\
\hline $\mathrm{S}_{1} \mathbf{Z n}_{0}$ & 160.44 & 12.00 & 0.49 & \multirow{3}{*}{\multicolumn{4}{|c|}{$\begin{array}{l}\mathrm{S}_{1}: 50 \mathrm{~kg} \text { seeds ha- } \\
\mathrm{S}_{2}: 75 \mathrm{~kg} \text { seeds ha } \\
\mathrm{S}_{3}: 100 \mathrm{~kg} \text { seeds ha }\end{array}$}} \\
\hline$S_{1} Z n_{1}$ & 167.88 & 12.33 & 0.50 & & & & \\
\hline $\mathrm{S}_{2} \mathbf{Z n}_{0}$ & 176.88 & 12.09 & 0.54 & & & & \\
\hline $\mathrm{S}_{2} \mathbf{Z n}_{1}$ & 182.08 & 12.48 & 0.58 & \multirow{3}{*}{\multicolumn{4}{|c|}{$\begin{array}{l}\mathrm{N}_{1}: 100 \mathrm{~kg} \text { nitrogen } \mathrm{ha}^{-1} \\
\mathrm{~N}_{2}: 125 \mathrm{~kg} \text { nitrogen } \mathrm{ha}^{-1} \\
\mathrm{~N}_{3}: 150 \mathrm{~kg} \text { nitrogen } \mathrm{ha}^{-1}\end{array}$}} \\
\hline $\mathbf{S}_{3} \mathbf{Z n}_{0}$ & 182.08 & 11.60 & 0.53 & & & & \\
\hline$S_{3} Z_{n}$ & 177.11 & 12.83 & 0.56 & & & & \\
\hline 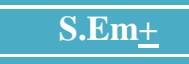 & 4.94 & 0.38 & 0.02 & \multirow{2}{*}{\multicolumn{4}{|c|}{$\begin{array}{c}\mathrm{Zn}_{0}: 0 \mathrm{~kg} \text { zinc ha } \\
\mathrm{Zn}_{1}: 10 \mathrm{~kg}^{-1} \text { zinc kg ha }\end{array}$}} \\
\hline CD at $5 \%$ & NS & NS & NS & & & & \\
\hline
\end{tabular}


Table.2 Dry matter accumulation and green fodder yield of fodder maize at harvest as influenced by different levels of seed rate nitrogen and zinc

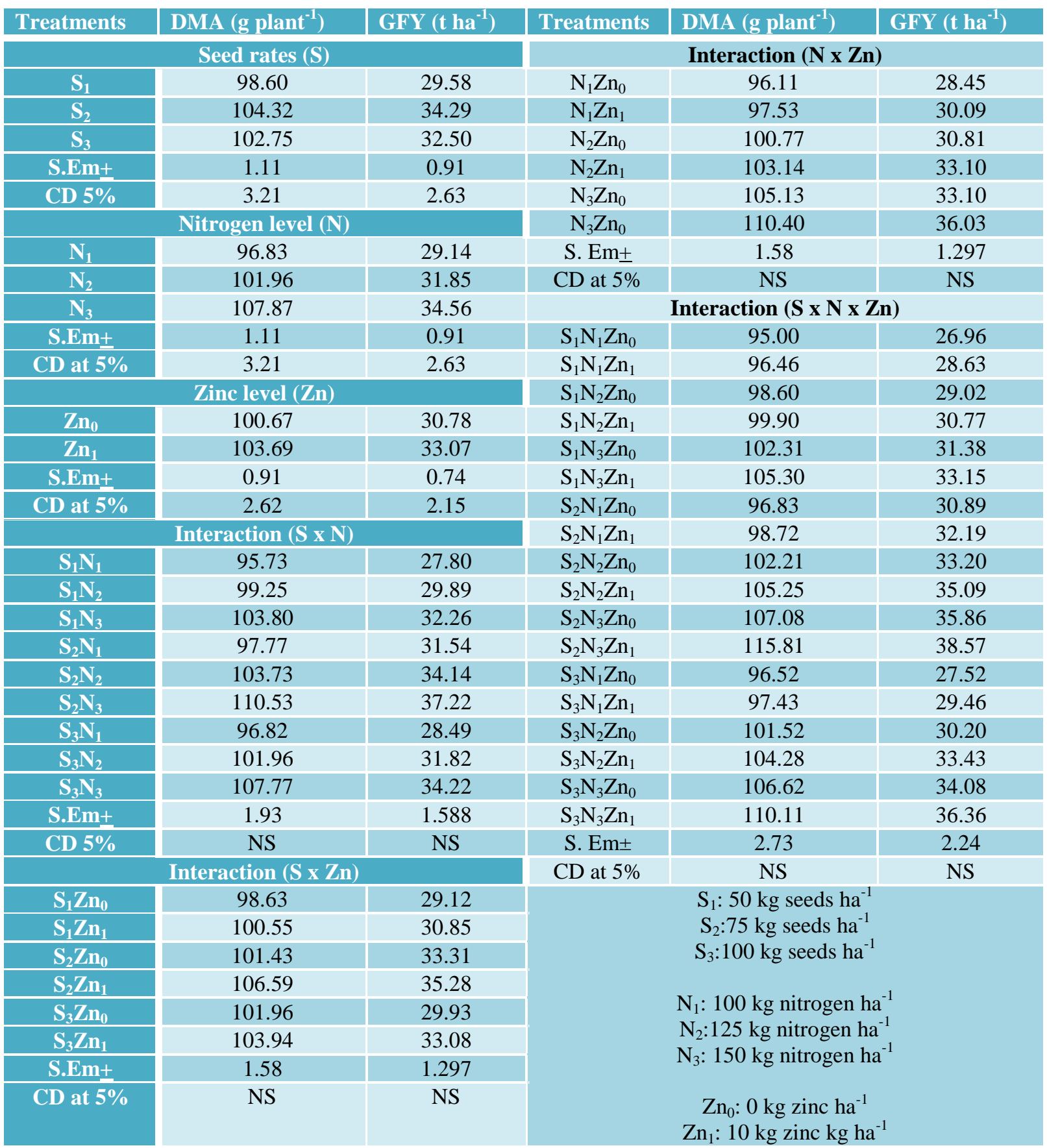

It was mainly due to rapid expansion of dark green foliage which could intercept and utilize the incident solar radiation in the production of photosynthates and finally resulting in higher meristematic activity and increased leaf stem ratio of fodder maize.
These results are conformity with the findings of Manjangouda et al., (2017) and Somashekar (2018). Application of zinc at 10 $\mathrm{kg}$ per ha caused discernible increase in leaf: stem ratio (0.55) over no zinc application (0.50). As zinc is involved in auxin synthesis 
which in turn induces cell division and as such higher cell division with zinc application would lead to increase in leaf: stem ratio. Increase in leaf stem ratio with zinc application has also been reported by Patel $e t$ al., (2007).

The interaction between seed rate, nitrogen and zinc levels on leaf to stem ratio was found to be non-significant.

\section{Dry matter accumulation}

Among the different seed rates $75 \mathrm{~kg}$ per ha recorded significantly higher dry matter accumulation (104.32 $\mathrm{g} \mathrm{plant}^{-1}$ ) as compared to $50 \mathrm{~kg}$ seed rate per ha $\left(98.60 \mathrm{~g} \mathrm{plant}^{-1}\right)$ and it was on par with $100 \mathrm{~kg} \mathrm{ha}^{-1}$ seed rate (102.75 $\left.\mathrm{g} \mathrm{plant}^{-1}\right)$. The higher dry matter accumulation in seed rate of $75 \mathrm{~kg}$ per ha was mainly due to higher plant height, leaf-stem ratio. Apart from this the over burden of the plant population which might compete for light and nutrients which leads to lanky growth and grassy shoot appearance resulted in lower dry matter accumulation in seed rate of $100 \mathrm{~kg} \mathrm{ha}^{-1}$. The results are in line with the findings of (Pathan et al., 2007; Somashekar et al., 2018) (Table 2).

The dry matter accumulation was significantly higher with application of nitrogen $150 \mathrm{~kg}$ per ha $\left(107.87 \mathrm{~g}\right.$ plant $\left.^{-1}\right)$ over $100 \mathrm{~kg}$ nitrogen per ha $\left(96.83 \mathrm{~g} \mathrm{plant}^{-1}\right)$. This may be attributed to nitrogen is an essential constituent of plant tissue and is involved in cell division and cell elongation, its beneficial effect on the growth characters viz., plant height and stem diameter. Earlier Eltelib et al., (2006) and Manjanagouda et al., (2017) also reported similar findings. Significant increase in dry matter accumulation of fodder maize (103.69 $\left.\mathrm{g} \mathrm{plant}^{-1}\right)$ with the application of $10 \mathrm{~kg}$ zinc per ha over no zinc application (100.67 $\left.\mathrm{g} \mathrm{plant}^{-1}\right)$. It might be due to zinc act as catalyst in various growth processes and in hormone production as well as in protein synthesis, which have increased the dry matter accumulation. Similar observations were observed by (Surendra mohan, 2015) and (Mehdi et al., 2012).

The interaction between seed rate, nitrogen and zinc levels on dry matter accumulation was found to be non-significant.

\section{Green fodder yield}

Significantly higher green fodder yield was recorded with seed rate of $75 \mathrm{~kg}$ per ha $(34.29$ $\left.\mathrm{t} \mathrm{ha}^{-1}\right)$ as compared to seed rate of $50 \mathrm{~kg}$ per ha $\left(29.58 \mathrm{t} \mathrm{ha}^{-1}\right)$ and it was on par with seed rate of $100 \mathrm{~kg} \mathrm{ha}^{-1}\left(32.50 \mathrm{t} \mathrm{ha}^{-1}\right)$. The higher green fodder yield in seed rate of $75 \mathrm{~kg}$ per ha was mainly due to higher plant height and leaf to stem ratio. Apart from this the over burden of the plant population which might compete for light and nutrients which leads to lanky growth and grassy shoot appearance resulted in lower green fodder yield in seed rate of 100 $\mathrm{kg} \mathrm{ha}^{-1}$. These results are in conformity with the findings of Pathan et al., (2007), Somashekar et al., (2018) and Patel et al., 1990).

Among the nitrogen levels significantly higher green fodder yield was recorded with application of $150 \mathrm{~kg}$ nitrogen per ha $(34.56 \mathrm{t}$ $\mathrm{ha}^{-1}$ ) compared to $100 \mathrm{~kg}$ nitrogen per ha $\left(29.14 \mathrm{t} \mathrm{ha}^{-1}\right)$ and $125 \mathrm{~kg} \mathrm{~N}$ per ha $(31.85 \mathrm{t}$ $\left.\mathrm{ha}^{-1}\right)$. This may be mainly attributed to improved growth and yield parameters, viz., plant height, leaf: stem ratio and the beneficial effects of nitrogen on cell division and elongation, formation of nucleotides and coenzymes which resulted in increased meristematic activity and photosynthetic area and hence more production and accumulation of photosynthates, yielding higher green fodder. The results are in agreement with the findings of Ayub et al., (2002), Joshi and Kuldeep Kumar (2007). 
Application of zinc at $10 \mathrm{~kg}$ per ha significantly improved the green fodder yield (33.07 $\mathrm{t} \mathrm{ha} \mathrm{ha}^{-1}$ ) of maize over no zinc application (30.78 $\left.\mathrm{t} \mathrm{ha}^{-1}\right)$. This increase in fodder yield due to zinc application might be the role of zinc in various enzymatic reactions. Zinc act as catalyst in various growth processes and in hormone production as well as in protein synthesis, which have increased the entire yield attributing parameters viz., shoot length, number of leaves, dry matter production etc. thereby final yield (Patel et al., 2007 and Parik et al., 1993).

\section{References}

Abdulgani Nabooji, Keshavaiah, K. V., Shirgapure K. H. and Shekara B. G., 2018, Effect of seed rates and nitrogen levels on growth and fodder yield of sweet sorghum. J. Pharmacognosy Phytochemistry, 7 (2): 1391-1394.

Ahmad, N., 2000, Fertilizer scenario in Pakistan policies and development. In: Proceedings of the Conference Agriculture and Fertilizer Use, ed. N. Ahmad, pp.15-21. Islamabad, Pakistan: Planning and Development Division, Government of Pakistan.

Ayub, M., Nadeem, M. A., Sharar, M. S. and Mahmood, N., 2002, Response of maize (Zea mays L.) fodder to different levels of nitrogen and phosphorus. Asian J. Pl. Sci., 1 (4): 352-354.

Bishnol, N. R., Mali, A. L. and Sumeriya, H. K., 2005, Fodder quality of dual purpose sorghum genotypes as influenced by varying plant population and nitrogen levels. Forage Res., 30 (4): 229-230.

Eltelib, H. A., Hamad, M. A. and Ali, E. E., 2006, the effect of nitrogen and phosphorus fertilization on growth, yield and quality of forage maize (Zea mays L.). Agron. J. 5 (3): 515 - 518.
Joshi, Y. P. and Kuldeep Kumar, 2007, Effect of nitrogen and seed rates on growth, yield and quality of fodder maize variety (African tall). Forage Res., 33 (3): 171-173.

Manjanagouda, S. Sannagoudar, Lalitha, B. S., Prajwal Kumar, G. K., Prashant and Bhavya, V., 2017, Effect of varieties, cutting and nitrogen management on green fodder yield, nutrient uptake, available soil nutrient status and economics of dual Purpose Pearl Millet (Pennisetum glaucum L.). Int. J. Curr. Microbiol. Appl. Sci., 6 (12): 214-226.

Mehdi, S. S., Husain, B. and Singh, L., 2012, Influence of seed rate, nitrogen and zinc on fodder maize (Zea mays L.) in temperate conditions of western Himalayas. Indian J. Agron., 57 (1): 8588.

Panse, V. G. and Sukhatme, P. V., 1967, Statistical methods for agricultural workers. ICAR, Publ., New Delhi, p.359.

Parik, B. L., Saxena, S. C. and Ali, M. H., 1993, Proceedings of the workshop on micro- nutrients, Bhubaneswar, India, pp. 214-222.

Patel, A. S., Sadhu, A. C., Patel, M. R. and Patel, P. C., 2007, Influence of nitrogen and zinc on maize (Zea mays L.). Forage Res., 34 (4): 209-212.

Patel, J. R., Patel, P. C. and Syied, M. R., 1990, Effect of seed rate and cutting stages on forage yield of maize varieties. Gujarat Univ. Res. J., 16: 15.

Phatan, S. L., Bhilare, R. L., Nawale, K. B. and Jadhav, V. T., 2007, Response of multi cut oat varieties to nitrogen levels. Forage Res., 32 (4): 269-270.

Shah, Z., Shah, S. H., Peoples, M. B., Schwenke, G. D. and Herriedge, D. F. 2003, Crop residue and fertilizer $\mathrm{N}$ effects on nitrogen fixation and yields of legume cereal rotations and soil 
organic fertility. Field Crops Res., 83: $1-11$.

Somashekar, K. S., Shekara, B. G., Vidyashree, D. N., Lalitha, B. S. and Bhavya, V., 2018, Effect of Different Seed Rates and Nitrogen Levels on Growth, Yield, Quality and Economics of Multi cut Fodder Sorghum (Sorghum sudanense L.). Int. J. Pure Appl. Bio. sci., 6 (1): 1108-1115.

Sood, B. R., Singh, G. and Kumar, N., 1994, Evaluation of maize fodder varieties for forage yield under different levels of nitrogen. Forage Res., 20 (2\&3): 208209.

Surendra Mohan, Magan Singh and Rakesh Kumar, 2015, Effect of nitrogen, phosphorus and zinc fertilization on yield and quality of kharif fodder -A review. Agric. Reviews, 36 (3): 218226.

Verma, S. K., Bhunia, S. R. and Yadava, D. K., 2005, Response of oat (Avena sativa L.) to cutting management, method of sowing and nitrogen. Forage Res., 27 (3): 167- 170 .

\section{How to cite this article:}

Tahira Begum, B.S. Lalitha and Subbarayappa, C.T. 2018. Effect of Different Levels of Seed Rate, Nitrogen and Zinc on Growth and Yield of Fodder Maize (Zea mays L.). Int.J.Curr.Microbiol.App.Sci. 7(09): 1128-1136. doi: https://doi.org/10.20546/ijcmas.2018.709.134 